\title{
Homeopathic medicines influence fungal adhesion and cellular oxygen metabolism of MDCK and MA104 cell lines
}

\author{
Carla Holandino ${ }^{1}$, Venicio Veiga ${ }^{2}$, Gleyce Moreno Barbosa ${ }^{1}$, Fortune \\ Homsani1 $^{1}$, Camila Monteiro Siqueira ${ }^{1,3}$, Antonio Galina ${ }^{4}$, Tatiana El-Bacha ${ }^{5}$, \\ Jose Nelson Couceiro ${ }^{2}$, Andre Luis Souza dos Santos ${ }^{2}$
}

(1) Laboratório Multidisciplinar de Ciências Farmacêuticas, UFRJ, Rio de Janeiro, Brasil

(2) Instituto de Microbiologia Professor Paulo de Góes, UFRJ. Rio de Janeiro, Brasil

(3) Instituto Federal de Educação, IFRJ. Rio de Janeiro, Brasil.

(4) Instituto de Bioquímica Médica, UFRJ, Rio de Janeiro, Brasil.

(5) Instituto de Nutrição Josué de Castro, UFRJ, Rio de Janeiro, Brasil

\begin{abstract}
Background: Fungal and viral infections constitute a serious public health problem, because morbidity and mortality rates of these diseases have been increasing in the last decades [1,2]. The resistance to antifungal and antiviral agents [3,4] currently available in the pharmaceutical market motivates the development of new therapies, including complementary and alternative health practices [5,6]. In this context, our research group has deepened the knowledge about the therapeutic potential of homeopathy using different models [7-9]. Homeopathic medicines undergo a process of serial dilution whereby the final remedy contains extremely low amounts of the active substance, with pharmacological action, and, consequently, cannot be considered merely placebos [10]. Aims: In the present study, we evaluated the potential of two different homeopathic medicines, named Influenzinum RC (compounded with influenza A virus) and Candida albicans RC (compounded with Candida albicans yeasts), which are prepared according to Brazilian homeopathic procedures [11]. Methodology: The biotherapics (12x, 30x) were prepared from Candida albicans yeasts [7, 11] and from influenza virus A H3N2 [6,11]. The cellular parameters evaluated after biotherapic treatments were: cytotoxicity by MTT assay; PFK-1 activity; and maximum respiratory capacity. Results: Our results showed that Influenzinum RC did not cause cytotoxic effects but induced morphological alterations, increased ( $p<$ 0.05) mitochondrial activity, and significantly modified ( $p<0.05)$ PFK-1 activity of MDCK cells. Additionally, using high-resolution respirometry we could detect a maximum respiratory capacity when these cells were treated with Influenzinum RC, despite a well-preserved ultrastructure of their mitochondrial organelles. In contrast, when MA104 cells were treated with Candida albicans RC, a significant decrease in cellular respiratory capacity as well as in yeasts adhesion rate was detected. Conclusions: These results indicate that homeopathic medicines modify important cellular and metabolic aspects of mammalian cells and these alterations should be responsible for the therapeutic potential of these drugs.
\end{abstract}

Keywords: Candida albicans, influenza A virus, homeopathy, in vitro models. 


\section{References}

[1] Akpan, A, Morgan, R. Oral candidiasis. Postgrad Medicine J. 2002; 78:455-459.

[2] Couceiro, JNSS. et al. Natural piperine as a new alternative against influenza viruses. Virus Rev Res. 2005; 10: 27-32.

[3] Barr, CE, Torosian, JP. Oral manifestations in patients with AIDS or AIDS-related complex. Lancet. 1986; 2: 288 .

[4] Monto, AS et al. Detection of influenza viruses resistant to neuraminidase inhibitors in global surveillance during the first 3 years of their use. Ant. Ag. Chem. 2006; 50 (7): 2395-2402.

[5] Holandino, C, Moreno, GB, Homsani, F, Veiga, VF, Santos, AL. Complementary and Alternative Health Practices Applied to Candida albicans Infections. In: BIT's 2nd Annual World Congress of Microbes. 2012; 2:220. Guangzhou, China.

[6] Siqueira, CM, Costa, B, Amorim, AM et al. H3N2 homeopathic influenza virus solution modifies cellular and biochemical aspects of MDCK and J774G8 cell lines. Homeopathy. 2013; 31-40.

[7] Homsani, F, Barbosa, GM, Silva, LFM, Siqueira, CM, Santos, LH, El-Bacha, T, Santos, AL, Holandino, C. Evaluation of alterations in adhesion rates of Candida albicans and in respiration cellular induced by Candida albicans type RC nosodes In: Proceedings of the XXVII GIRI Symposium. 2013; 12:152-153. Bern, Switzerland.

[8] Garcia, S, Harduim, RC, Homsani, F, Zacharias, CR, Kurster, R, Holandino, C. Physical chemical and citotoxic evaluation of highly diluted solutions of Euphorbia tirucalli L. prepared through the fifty milesimal homeopathic method. Int J High Dil Res. 2010; 9:63-73.

[9] Bortolini, R, Bonamin, L, Holandino, C. Putative protective effect of Cadmium chloride high diluted solution on LLC-PK1 cell intoxicated by high concentration of this same metal: an isopathic in vitro assay. Int J High Dil Res. 2010; 9:16-29.

[10] Bellavite, P, Marzotto, M, Olioso, D, Moratti, E, Conforti, A. High-dilution effects revisited. 1. Physicochemical aspects. Homeopathy. 2014; 103: 4-21.

[11] Brasil. Brazilian Homeopathic Pharmacopea, 3ed, 2011.

\section{(c)) BY-NC-ND Licensed to GIRI}

Support: Capes, Faperj.

Conflict of interest: authors declare there is no conflict of interest

Received: April $8^{\text {th }}$ 2014; Revised: May 10 ${ }^{\text {th }}$ 2014; Published: June 30 2014.

Correspondence author: Carla Holandino, cholandino@gmail.com.

How to cite this article: Holandino C, Veiga V, Barbosa GM, Homsani F, Siqueira CM, Galina A, El-Bacha T, Couceiro JN, dos Santos ALS. Homeopathic Medicines Influence Fungal Adhesion and Cellular Oxygen Metabolism of MDCK and MA104 Cell Lines. Int J High Dilution Res [online]. 2014 [cited YYYY Month dd]; 13(47): 97-98. Proceedings of the XXVIII GIRI Symposium; 2014 Jun 20-22; Sighisoara (Romania). GIRI; 2014; Available from: http://www.feg.unesp.br/ ojs/index.php/ijhdr/article/view/736/698 